\title{
Aspects regarding a mining area rehabilitation for post-industrial tourism
}

\author{
Mihaela Toderas ${ }^{1}$, Ionela Samuil ${ }^{1}$, Andreea Ionica ${ }^{1, *}$, Marius Olar $^{1}$, and Stefan Militaru ${ }^{1}$ \\ ${ }^{1}$ University of Petrosani, 332006, Romania
}

\begin{abstract}
The main problem of former industrial areas with history of mining exploitation is the impact of specific activities both on the environment as well as on the social and economic life of the population. In this context, we talk about the Jiu Valley, a mono-industrial area where significant environmental degradation is observed and which did not benefit from economic diversity policies. The aim of this paper is to identify possibilities for the rehabilitation of the Petrila mining perimeter and its potential use in a touristic circuit that adds value to constructions declared historical monuments, dating back to 1850 , such as the central shaft and the skip, the old compressors, treatment and the mechanical workshop.
\end{abstract}

\section{Introduction}

The extraction and processing activity of useful mineral substances is one of the oldest occupations of humankind and constituted, over time, the main stimulus of human society development. The world economy and implicitly the national economies are in a constant hunger for resources, which must be satisfied either by exploiting their own deposits of useful mineral substances or by importing them [1-5].

The mining industry has met many changes throughout the world over the past two decades. Thus, a mine closure process has taken place in Western Europe, in the East of the continent where a major restructuring and reorganization of the ex-communist states economy has been and is still taking. In the member states of the European Community there was a noticeable decline in the extraction and processing activity of useful mineral substances $[5,6]$.

If the theoretical and practical aspects of environmental engineering, have been discovered and implemented quite late, the achievements of some works in rock massifs for the purpose of exploiting of useful deposits, are very old. The great achievements did not wait for the supporting theoretical applications, but nowadays, the engineer and not only, must not ignore the fundamental principles underlying the reinstatement in the natural circuit of the areas that are affected by the mining exploitations. In the area of active exploitation, the environment is the most affected. It should be noted that several elements of the exploitation flow have created significant effects on the environment.

The world priorities in the field of environment protection must comply the international criteria, from which we mention: the degree of identification and the hazards

* Corresponding author: andreeaionica@upet.ro 
impact area; the possibility of unforeseen hazards occurrence; the environment period of destruction.

The extractive industry is operating where useful mineral substances are found. The volume of activities is very high, so settlements and even industrial areas are developing on these surfaces, causing natural ecosystems to be replaced by heavily anthropogenic spaces [7-10].

The use of heavy equipments, the construction of roads, the occupation of large areas for excavation, surface construction and storage of materials are just some of the causes behind landscape transformation. Mining areas are often described by the term of "lunar landscape", which suggests, on one hand the unfavourable conditions for life, but also the occurrence of a new type of landscape, strongly different from the natural one. The evolution of these areas can occur in two directions: either by total or partial abandonment, either by functional or structural conversion of these sites $[4,6,7,11,12]$. However, this involves the following main steps, related to: analysis of previous experiences, supplemented with information regarding the obtained results by professionals in this field; assessing the acceptability of such a reconstruction project of the affected areas by the mining activity, based on qualitative, quantitative, economic and juridical analysis according to the actual legislation; the principle of multiple uses, involving the knowledge of the interactions between the subsequent use of the affected surface by the mining exploitation, as a decisive element in the implementation of a post-industrial reuse project [13-15]. The achievement of project based on the use of spatial data, the knowledge of site and the development of the method for analysing each element potential in the considered perimeter, highlighting the interactions between uses in a given context. Worldwide, such studies have been realized in order to develop a methodology for implementing of multipleuse approximation, research that addressed issues related in particular to landscaping $[1,2,5,16,17]$.

\section{Presentation of underground mining works and Petrila mine location}

Given the reserve per unit area, coal quality, experience in mining exploitation and the possibility of increasing production, Jiu Valley basin was until recently the most important coalfield of our country. Due to its complicated geological structure, intensively affected tectonics, with variations within very wide limits of size respectively its qualitative and quantitative parameters, this basin is part of the $3^{\text {rd }}$ group of geological complexity $[8,14]$. From the hydrogeological point of view, with some small exceptions, it does not imply major difficulties. Regarding gaseous-dynamic regime, is classified in the $4^{\text {th }}$ category after the emanations of methane. Due to the great depth of exploitation, types of rocks surrounding the deposit, variations in thickness and inclination of the coal strata, this basin has and also raised the most difficult and interesting problems in the extraction process, problems that must be solved in the future. Based on data provided of existing documentation at the mines from Jiu Valley basin, the opening over the years, after exploitation of outcrops in quarry, was carried out with main galleries. Because of its advantages, the opening with adits remained present for certain areas of Jiu Valley basin. Of adits were tied blind shafts, cross and directional galleries, to exploit in depth. Opening with vertical shafts from surface was done while maintaining in exploitation the existing adits and blind shafts. As a result, the opening scheme applied and generalized to all mines from Jiu Valley can be synthesized by the following: the horizon of base serves on the opening of all layers; the presence of many tectonics blocks determined their opening separately; the location of the main opening mine workings the decisive factor was the 
geological structure and the possibilities of their location on the surface. However it should be made clear that no documentation has shown any optimization studies of these locations.

The mining exploitation in the Petrila perimeter area was well known before the coal extraction started; the mining tradition of this area began with the alluvial exploitation of gold, its extraction being made by digging some circular shafts until a certain depth. On this depth, between the layers that formed the basement there was hidden a yellow-greenish mud in which there were undefined forms of gold [8].

The exploitation works of coal at the Petrila mine, considered the standard mine for the Jiu Valley colliery, began in 1840 (otherwise, the first works from Petroşani colliery), have intensified in 1859, taking an even greater development after 1870 . The adit opening from Deak mine (the future Petrila mine) was the first major work digged in the Petrila mining field at a level of $634.3 \mathrm{~m}$. Towards the end of 1869 , a vertical shaft was excavated, the Deak shaft, being initially used to accomplish the ventilation, and later it was arranged as a transport shaft of Deak mine. The development of the network of opening and preparation of new production capacities continued by deepening of extraction shaft, the digging of the central extraction shaft, which also had the role of ventilation shaft of mine (Figure 1).

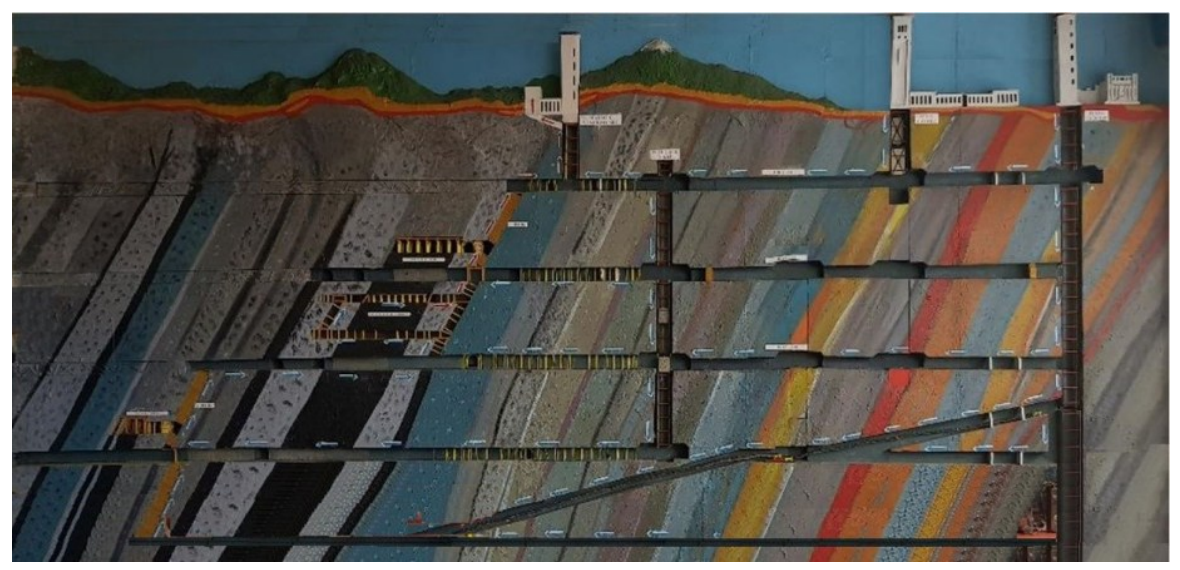

Fig. 1. Development of the underground mining works network.

The large diversity of geo-mining conditions from Jiu Valley basin: tectonic, variety of rocks, thickness and inclination of coal strata, depth, shape the landscape, the evolution of mining technology; have led, over time, to the application of different exploitation methods and work technologies in the extraction process of coal, aiming to have higher technical and economic indicators. From the point of view of the depth of exploitation, Petrila mine was the deepest from Jiu Valley colliery ( $850 \mathrm{~m}$ depth). The variation of depth emplacement of mining works was imposed by the geotectonic that characterized this mining perimeter [14].

\section{Rehabilitation solution of location mine}

The main issue of former industrial areas characterized by a history regarding mining exploitation is both the impact of specific activities on the environment as well as on the social and economic life of the population in these regions. In this context, we talk about Jiu Valley, a mono-industrial area where significant environmental degradation is observed and which did not benefit from economic diversity policies. As a result of the former coal exploitation, tens of hectares are empty or occupied by old buildings, prepared for demolition and decommissioned equipments. Although at this stage the Petrila mine is a rather desolate landscape, it could become the main objective to be visited in the area by organizing a touristic circuit that would unite, in an interesting manner, the most 
representative buildings within the surface mining perimeter, for a more detailed presentation of exploitation methods and technologies and also the working conditions at different stages of exploitation.

The objective regarding the development of a touristic and recreation centre on the site of the Petrila mine implies a complex of provided works for the reconstruction up to a certain degree of the mining activity practiced until recently in this area.

For the redevelopment of surface corresponding to the Petrila mine location, it is necessary to provide certain operations related to: removal of old mining equipment; decommissioning of the processing plant; stabilizing and landscape painting redevelopment of location.

\subsection{Synthesis of existing works}

In the reconversion project is required as a necessity, the preservation of landscape features, biodiversity, ethno-folkloric and cultural values, the development of harmonious relationships between nature and society through the promotion of activities without environmental impact $[2,7,12,15]$.

The Petrila mine's location includes a series of constructions achieved to serve the administrative area and the production process, from extraction to transport the coal production at the treatment plant to the surface: the administrative building; the school of qualification and the school mine; the dispensary; the gangway of the miners for crossing the railway; the centre shaft assembly; the old compressor building and the mechanical workshop; the treatment plant and its concrete basins; the coal extraction sector made up of skip shafts, sorting station with silos, the conveyor belts, the angular stations, the ventilating fans and the new compressor building; Deak shaft; the old thermal power station and the chimney; the funicular area; the railway; the tailings dumps.

The Deak shaft, the mechanical workshops, the compressor building and chimney, the shaft with skip, the center shaft with the tower and the hall, the old treatment plant with coal-laundering were listed on the industrial heritage list [18] (Figure 2).

\subsection{Proposed touristic tour}

As a proposed solution, the former Petrila mining perimeter can be conceived comprising two sections: one referring to the specific surface works and the other to the subterranean. The access route of visitors to the underground and mining works that may be included in the underground circuit are not covered by this work, so no reference will be made to this.

Taking into account the blasting of each building in the Petrila Mining Perimeter, their positioning and the function held until the moment of the mine closure, the project for realization on the surface of the future Petrila Theme Park will be proposed, comprising the following objective (Table 1): 1. Dispensary; 2. Administrative building; 3. School Mine; 4. Mechanical workshop (1879); 5. Sorting station; 6. Treatment plant; 7. Shaft Center Tower and Hall (1938); 8. Shaft with Skip (1987); 10. Compressor building (1879); 11. Thermal power station with chimney (1912); 11. Old treatment plant with washing coal; 12. Shaft Deak (1868); 13. Basin from treatment plant; 14. Funicular.

In order to attract visitors, it is necessary to offer a journey in time and space, which is also an educational experience to discover the life of mining, both in the underground and the surface. The underground reveals the fascination to penetrate to a certain extent, as much as nature allows in the mysterious history of land formation, to cross the mining network and experience the underground work experience. On the other hand, given the historical load characterizing this mining perimeter, the surface attractions will include (Figure 3): 
The Dispensary becomes an information center, where the visitor will receive general information on important perimeter objectives as well as various informative leaflets. Everything from here will be able to rent augmented reality devices with which they will easily penetrate the mysteries of the place.
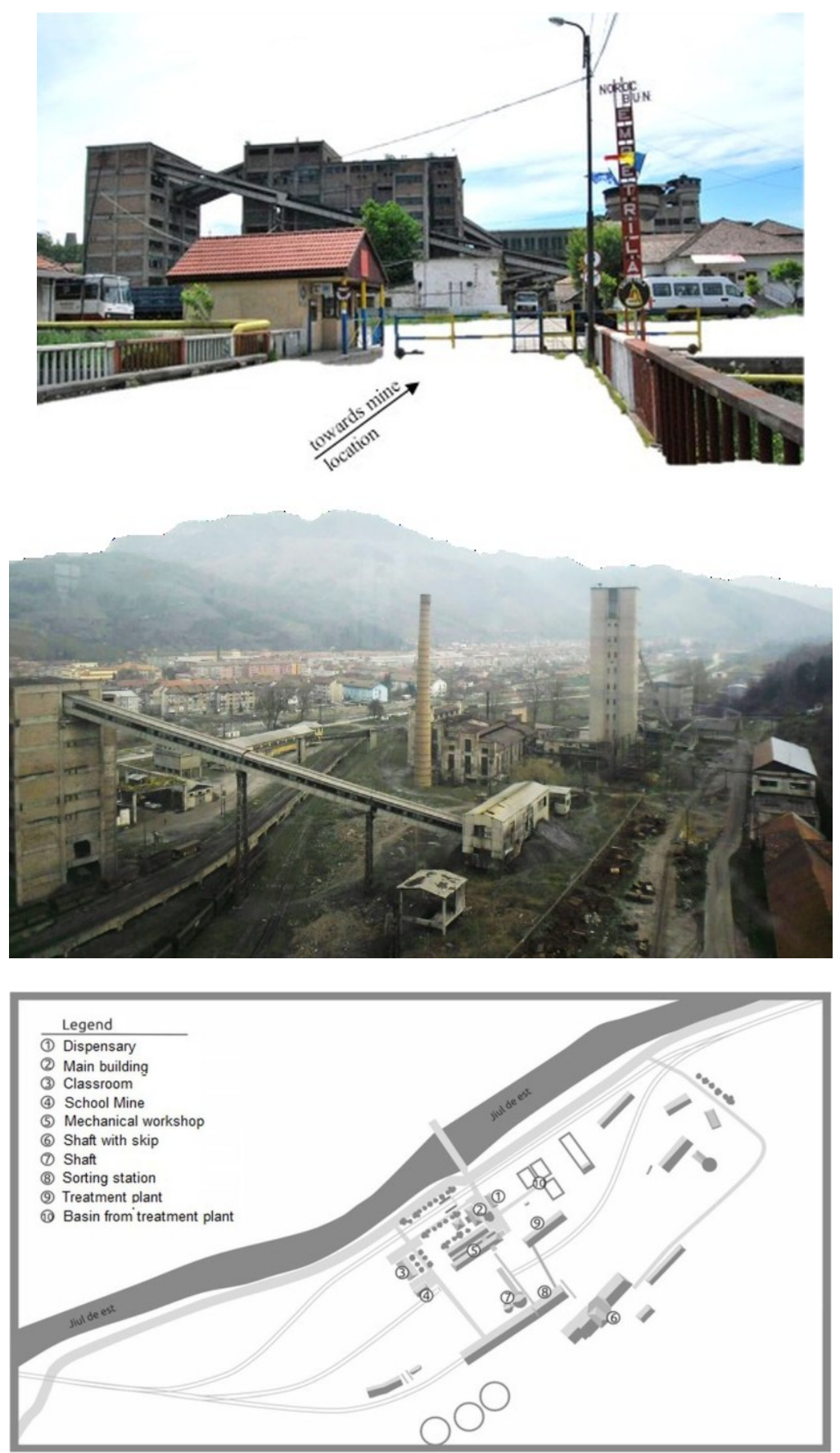

Fig. 2. Mine's location and constructions related to the extraction - transport - coal preparation process 
Table 1. Specific constructions to the Petrila mine location

\begin{tabular}{|c|c|c|}
\hline Objective & Previous purpose & Current function \\
\hline $\begin{array}{c}\text { Dispensary (Medical } \\
\text { Office) }\end{array}$ & Ensuring medical assistance & Tourist Information Centre \\
\hline Administrative building & Offices spaces & Museum \\
\hline Railway with coal lorry car & Transport on surface & Section of the museum \\
\hline School Mine & $\begin{array}{l}\text { Training facilities for new } \\
\text { employees }\end{array}$ & $\begin{array}{c}\text { Audio-video presentation } \\
\text { center }\end{array}$ \\
\hline Mechanical workshops & $\begin{array}{c}\text { Repair of mining machine and } \\
\text { equipment }\end{array}$ & $\begin{array}{c}\text { Presentation center of } \\
\text { experimental mineralogy }\end{array}$ \\
\hline Compressor building & $\begin{array}{c}\text { Production of required } \\
\text { compressed air }\end{array}$ & $\begin{array}{l}\text { Cultural Center and Art } \\
\text { Gallery }\end{array}$ \\
\hline $\begin{array}{c}\text { Thermal power station with } \\
\text { chimney }\end{array}$ & Production of energy & Section of the museum \\
\hline Sorting station & $\begin{array}{l}\text { Sorting coal by granulometric } \\
\text { classes }(20-30,30-50,50- \\
\quad 80 \mathrm{~mm})\end{array}$ & Section of the museum \\
\hline Treatment plant & Processing coal & Section of the museum \\
\hline Basin from treatment plant & Washing coal & Pond \\
\hline Shaft center & Material and staff transport & Section of the museum \\
\hline Shaft with skip & Transport of production & Section of the museum \\
\hline Deak shaft & $\begin{array}{l}\text { Initially as ventilation shaft and } \\
\text { then as transport shaft }\end{array}$ & Section of the museum \\
\hline Funicular & $\begin{array}{l}\text { Transport of blank (mine waste } \\
\text { or tailings) to waste dump }\end{array}$ & Ropeway \\
\hline
\end{tabular}

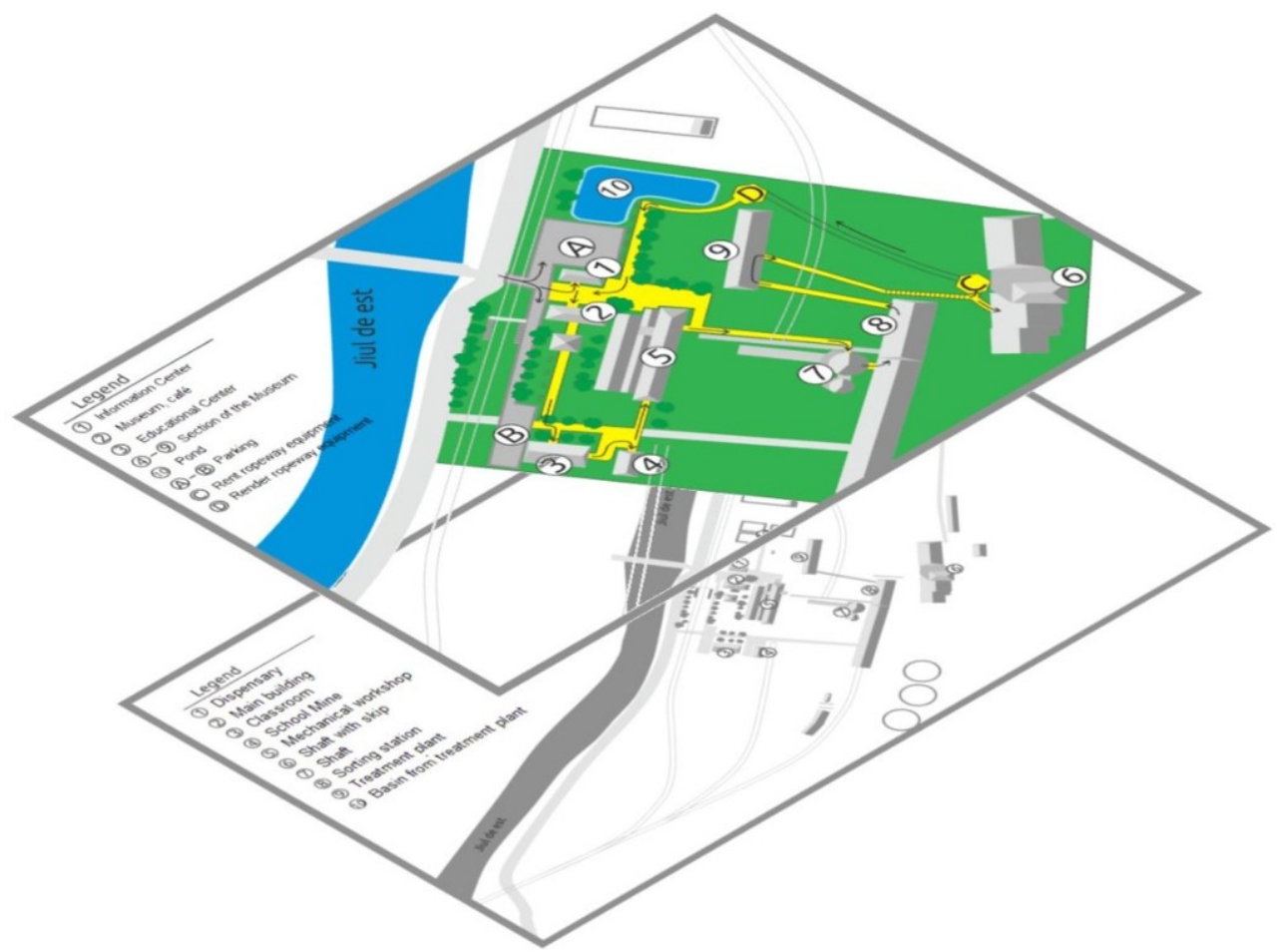

Fig. 3. Proposed model for redevelopment of the mine location and possible tourist route 
The Administrative Building - the starting point to the depths. It housed at the level of the ground floor the hall, the lamp, the showers as well as the underground entrance area and the upper levels of the various offices. All the area that served the miners' route, from the entrance to the cages, will be refurbished and presented in situ, the rest of the building will be re-divided and arranged for the organization of cultural activities with local theme as well as the arrangement of an art gallery with exhibits of local artists, and not only. At a higher level, it is desirable to arrange a café with the use of already existing rudimentary massive banks in the enclosure, placed as intruders among the measuring and testing devices, as evidence of past activities and the installation of glass walls will allow the contemplation of vestiges from the former mining perimeter. There will also be a screening room where educational films will be held, with information on both the development of the area in time and the habits of the place as well as the technological process and the life of the miners.

In order to serve the public, there will be several arrangements: dressing rooms equipped with protective equipment; social groups; powered by electricity and water supply. The size of these spaces justifies the development of a complex tourist center that provides visitors with comfort, information, displays, conference areas and small-scale discussions and at the same time a ticket house and a shop.

The School of Qualification, as an educational center, including teaching laboratories equipped with equipment to determine the geomechanical characteristics of rocks, groundwater analysis and environmental analysis, where high school students and students can practice lab classes.

The School Mine, a model coal mine, a low scale underground, will be the strength of the tourist circuit as it will enable visitors to get acquainted with what it means underground and underground work and have the closest the real experience of miners' lives in coal mines. This objective will include examples of methods of excavation and support for underground mining works, methods of exploiting coal strata and possibly in different periods of application. Thus, will be kept the gallery excavated in the sterile rock and the abatement front where all the technological operations that were underground in different places of work can be traced, respectively the equipment and the support of the works, respectively the abatement.

The preparation basin will be turned into a pond by lining the bottom of the pond with waterproofing foil, installing a geotextile foil, adding a layer of river gravel and sediment, and arranging aquatic plants surrounded by greenery and populating ornamental fish to enjoy the eye of the viewer and will fill the soul of peace and beauty.

The funicular will be replaced by a flying fox that will satisfy the need for adventure and at the same time provide a panoramic view of the area.

All other objects included in the circuit, already declared historical monuments and included in the National Heritage, will be reconditioned and presented in situ.

In addition to these objectives to be preserved, restored and redesigned, it is necessary to arrange a modern car park to serve the needs of tourists and to set up access roads in the tourist area. At the same time, the virgin space left behind the mine closure process, it is proposed to place a micro-farm of solar panels to provide the energy needed for the operation of this facility, thus transforming the project into an ecological one.

For emergency interventions there will be trained personnel for emergencies. Figure 3 represents the proposed model for rehabilitation of the mining site for tourism purposes, with the marking of the future destination envisaged for each of the considered spaces and constructions.

The surface transformed into a touristic circuit will be zoned so that the visitors will have the opportunity to know the succession of the technological processes that the miners made both on the surface and in the underground, from the entrance in return to the exit 
from the working front. At the same time, it will be possible to know and watch by various audio and/or video means, chronologically, aspects regarding the evolution and meaning of mining for the inhabitants of the area, the technological, economic, cultural, demographic and social impact that the activity had on the population and what meant end of activity. We can also use modern technologies to enhance tourists' experiences [19]. With an augmented reality device, the fragments of the usual miners' lives (e.g. lifting the lamp before entering the underground) can be overlapped in the perimeter visited for greater accuracy of the information. Augmented Reality is a technology that allows digital content to be added to the real world using different devices, making a symbiosis between the past and the present, so history can be "lived". In addition, it could lead to an increase in the youngsters' interest in the past and the cultural heritage.

The main advantage of the proposal is the reconstruction and reintroduction of the edifices in the economic circuit, keeping the original exterior appearance, the tourists having the opportunity to know and to understand the role and the importance of the extractive activity.

\section{Conclusions}

The underground and surface construction fields of the environment are developed on an international scene; whenever a step forward in research is achieved anywhere in the world, the whole world can benefit from the results almost immediately. But this internationalism does not have to mean uniformity; however, the originality of studies depends on the resources at our disposal, on each of ours experience capability of carrying out spectacular or bold works, based on an approach marked by the desire to exceed simple empiricism.

The implementation of this project can have a positive impact only if the achieved tourism product is viewed in terms of its long-term existence with the purpose of obtaining positive effects, such as: increasing employment opportunities, improving the infrastructure, improving the quality of life, changing the image about a specific place, better environmental protection, etc. In this context, this form of tourism can be the starting point for making investments, small businesses, new jobs, but without allowing the emergence of imbalances due to uncontrolled economic growth.

From an economical point of view, the improvement of this area as a museum requires relatively large investments but that can be recovered within a reasonable period of time. To these, the human resources involved in this museum complex can be added too, and Petrila city will remain an active area.

It is often difficult to establish what is positive and negative in tourism development and that, because although the impact is positive in the short term, it may be baleful in the long term. Attracted by the natural patrimony and wealth of anthropic vestiges the tourists will come, but if this wealth is not protected, the environment will degrade and the tourist destination will lose its attractiveness. And, we must not forget that the same force that acts to attract tourists, once the degraded patrimony, will work in the opposite direction and with the same intensity, moving away the tourists, leaving behind a population which must endure the consequences due to degradation of the living environment, natural resources and the decrease of incomes from tourism.

\section{References}

1. A. Ionica, M. Toderas, A. Patru, International Scientific Symposium, Management of Sustainable Rural Development, Seria I, XI, 100-115 (2009) 
2. A. Ionica, M. Toderas, A. Patru, International Scientific Symposium, Management of Durable Rural Development, Seria I, XI, 115-120 (2009)

3. G. Pascu, J. Bayon, T.O. Gheorghiu, Proceedings of the International Conference Central Europe towards Sustainable Building CESB13 (Prague, 2013)

4. M. Toderas, C. Danciu, Stability analysis methods of underground mining works. (LAP Saarbrücken, 2017)

5. Euracoal, Coal industry across Europe (European Association for Coal and Lignite, 2008)

6. M. Antrop, Landscape and Urban Planning, 70, 1-2 (2005)

7. A. Gavrilidis, C. Ioja, I. Saghin, Proceedings of the $47^{\text {th }}$ ISOCARP Congress (2011)

8. L. Jelinski, T.E. Graedel, R.A. Laudise, D.W. McCall, C.K.N. Patel, Proceedings of the National Academy of Sciences of the USA, 89 (1992)

9. T. Pindor, L. Preisner, $21^{\text {st }}$ World Mining Congress \& Expo 2008. New Challenges and Visions for mining (Krakow, Poland, 2008)

10. I.E. Pop, Monografia geologica a Bazinului Petrosani (EAR, Bucureşti, 1993)

11. M. Jonsen-Verbeke, Tourism Geographies: An International Journal of Tourism Space, Place and Environment, 1, 1 (1999)

12. M. Toderas, A. Ionica, International Journal of Environmental Science, 2 (2017)

13. D. Cole, Journal of Sustainable Tourism, 12, 6 (2014)

14. Z. Kruczek, M. Kruczek, Polish Journal of Environmental Studies, 25, 2 (2016)

15. M. Mazilu, Revista de Marketing Online, 1, 4 (2007)

16. M. Lamparska, M. Chmielewska, Sociologie Romaneasca, 10, 3 (2012)

17. M. Stratton, Industrial Buildings Conservation and Regeneration (Taylor and Francis, London, 2000)

18. C. Jujan, T. Svoboda, Mina Petrila 150 ani de activitate in mineritul industrial (Grafica Plus, Deva, 2009)

19. S. R Rosca, M. Leba, MATEC Web of Conferences, 121 (2017) 